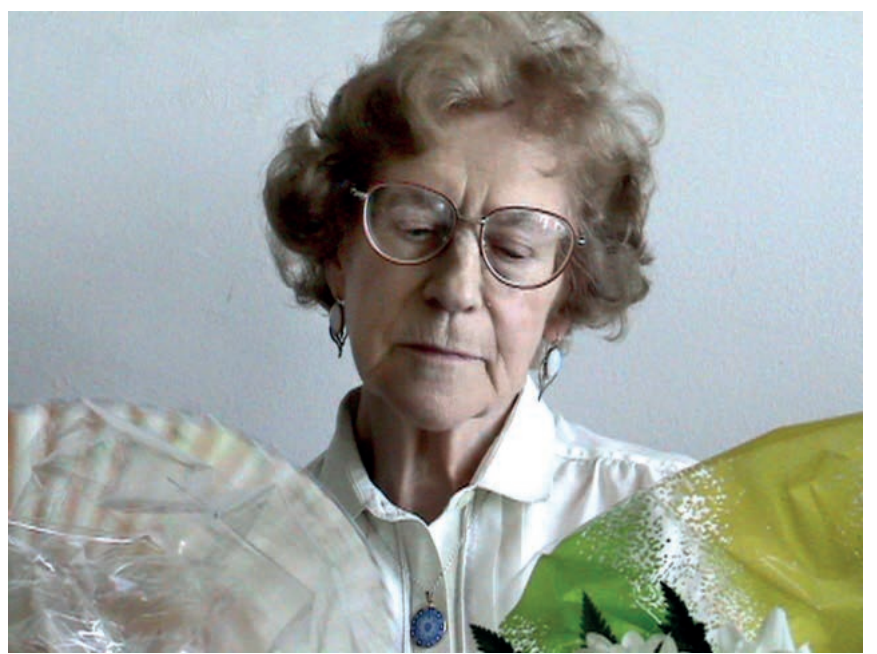

Об Оксане Герасимовне Гецовой. Вместо некролога

\title{
On Oksana Getsova. Instead of Obituary
}

Оксана Герасимовна Гецова (1925-2019) скончалась 13 января 2019 года, на 94-м году жизни. Всю свою жизнь Оксана Герасимовна посвятила родному филологическому факультету. Кандидат наук, доцент, много лет она преподавала дисциплины исторического цикла (старославянский язык, историческую грамматику), лексику и русскую диалектологию. Но главным в ее жизни стал «Архангельский областной словарь».

Оксана Герасимовна всегда была неутомимым борцом. Сейчас это кажется странным, но Словарь Оксане Герасимовне в свое время пришлось «пробивать». Сначала на родной кафедре. Одновременно было подано два проекта «Архангельского словаря». Но В.В. Виноградов поддержал проект Гецовой. Потом началась борьба с Академией. Ф.П. Филин, обгоняя эпоху, задумал и уже начал издавать сводный словарь русских говоров: знаменитый сейчас «Словарь русских народных говоров» (СРНГ), куда вошли все значительные диалектные словари XIX в., включая словарь В.И. Даля, и многие картотеки так и не вышедших (увы!) региональных словарей XX в. Федот Петрович был готов включить в СРНГ и материалы архангельской картотеки МГУ. Оксана Герасимовна отстояла свой Словарь как самостоятельное издание, и в первых десяти выпусках, даже после смерти Филина, продолжала борьбу: на одной из вступительных страниц указывала, сколько в АОС включено слов и значений многозначных слов, не учтенных в СРНГ.

Оксану Герасимовну всегда отличала замечательная лингвистическая интуиция. Она разработала принципы создания «Архангельского областного словаря», организовала полевую практику: в экспедиции по сбору материала для АОС одновременно выезжало несколько мелких групп по 4-6 человек, работая в разных деревнях. На камеральной практике студенты, оставшиеся в Москве, расписывали экспедиционные тетради, расставляли карточки в алфавитном порядке, вливали их в «большую» картотеку, расшифровывали аудиопленки и тоже расписывали их на карточки. Бумажная картотека АОС оценивается примерно в 5 млн карточек. 
Оксана Герасимовна всегда была открыта для всего нового. Она с восторгом приняла компьютерную революцию, хотя сама за компьютером никогда не работала. Она дала добро на создание Электронной картотеки, но была осторожна: поначалу тетради одновременно и расписывались на бумажные карточки, и вводились в компьютер. ОГ была поражена, когда через 2-3 года после начала работы появился материал для следующего выпуска уже и из электронной картотеки. Сейчас Электронная База насчитывает ок. 2 млн «карточек».

Оксана Герасимовна была максималистом. 20 лет она собирала материалы, прежде чем в 1980 г. был издан первый выпуск АОС. «Обратный словарь архангельских говоров», вышедший в 2006, содержит ок. 170 тыс. лексем. Сейчас объем Словаря определяется в 200 тыс. лексем. Когда ОГ только задумалась о создании Словаря, она не могла представить себе его масштаб и объем. Она просто работала так, как считала правильным, как ее научил ее любимый учитель - Рубен Иванович Аванесов.

- Оксана Герасимовна, мы ведь с Вами максималисты...

- ??? Я так о себе никогда не думала. Да, получается, что я максималист.

Оксана Герасимовна была увлекающейся натурой. Помимо того что она увлекалась людьми, она в разные годы своей жизни увлекалась то невероятным ремонтом квартиры, то дачей-садом-огородом (и давала советы бабушкам в деревне, как надо сажать огурцы-помидоры и все прочее. Бабушки послушно внимали). Воспитанная как настоящий советский человек, в эпоху гласности она бросилась читать всю разоблачительную литературу и до последних дней оставалась верна радио «Эхо Москвы». Воспитанная в профессорской семье в строгости и аскезе, она очень скромно одевалась, презирала бижутерию, - но вдруг оказалось, что у нее прекрасный вкус: она полюбила элегантную одежду и уральские самоцветы. В 1990-е гг. после отмены цензуры она познакомилась с поэзией Баркова. Она не очень понимала, как относиться к такого рода литературе, но все простила Баркову, когда заметила, что некоторое обсценное слово у него сохраняет двойствоенное число.

Оксана Герасимовна была неутомимой путешественницей, всегда была легка на подъем. В экспедиции она ездила ежегодно с середины 1950-х до 1989 г. В молодости бывала в странах так называемого соцлагеря: в Сербии, Болгарии, Венгрии и некоторых других. Как только исчез железный занавес, она побывала в Италии, Германии, Франции, Бельгии, Исландии, Мексике - это далеко не полный перечень ее путешествий, тем более что она в силу возраста и еще некоторых причин предпочитала круизы: круиз по Средиземному морю с заходом в Египет, круиз по Северным морям...

Оксану Герасимовну всегда отличало умение дружить. В деревнях, где ей довелось работать, ее помнили много лет: «Герасимовна-то жива еще? Передавай привет». Любимая информантка приезжала к ней в Москву и жила в ее доме. Оксана Герасимовна много лет дружила со своими учениками, с родителями учеников, с друзьями сына и с родителями этих друзей; с теми, кого случайно встретила в санатории, в поезде; с врачами, у которых лечилась, - всем им она обязательно рассказывала о Словаре, часто дарила очередной вышедший том.

В МГУ Оксана Герасимовна училась в одной группе с Татьяной Григорьевной Винокур и Еленой Федоровной Васеко. Татьяна Григорьевна рассказывала, что Оксана Герасимовна могла прийти к ней посреди ночи в любое время без предупреждения (речь идет вовсе не о студенческих годах) и поднять подругу с посте- 
ли: «Танька, ты что, спишь? Еще рано!» Сама талантливый человек, Оксана Герасимовна чувствовала талантливых людей - от студентов до академиков. Она искренне их любила, быстро привязывалась, старалась не упускать из поля зрения. Среди ее друзей были многие члены кафедры русского языка, Наум Коржавин, Леонид Леонидович Касаткин и Розалия Францевна Касаткина, Юрий Дереникович Апресян и Марина Яковлевна Гловинская и многие, многие другие.

Оксана Герасимовна любила помогать людям. Она любила много говорить. Но она прекрасно умела слушать. Умение слушать, наверное, является профессиональной чертой диалектолога. Такое множество друзей у нее было, возможно, именно потому, что она умела слушать. И расспрашивать. О том о сем. О важном и неважном, о семье, о планах, о работе. Много лет она ничем не болела. И искренне считала, что если человек заявляет, что болен чем-то, кроме простуды, то это для того, чтобы отдыхать и ничего не делать. Но болезни понемногу стали заявлять о себе, и тогда она пересмотрела свои взгляды. Серьезно выясняла причины и следствия болезни, методы лечения. Она очень внимательно относилась к своему здоровью. Искала хороших врачей, ходила в спортивные и всякие разные группы (даже то ли по стеклам ходила, то ли по углям). А потом делилась полученными знаниями: советовала врачей и клиники, рассказывала, какие лекарства от чего помогают, доставала лекарства; мне вот в свое время рекомендовала дыхательное упражнение, с помощью которого я за пару лет вылечила астму.

Оксану Герасимовну всегда отличал неиссякаемый оптимизм. Когда в 1980 г. вышел первый выпуск Словаря, она уже понимала, что не доживет до конца издания. И назначала себе срок: дожить до выпуска Словаря на... букву (никому не говорила, на какую). Потом - дожить до какой-то следующей буквы... Сама она была автором и редактором 1-12 выпусков. Но много словарных статей написала далеко вперед. Сейчас вышел 19-й выпуск, до конца буквы 3- осталось еще 2-3 года. (Слова на букву 3- начались в 15 выпуске, закончатся, по-видимому, в 21. Или в 22-м.) И в жизни она тоже была оптимисткой. Уже в старости она начала часто падать: «Ира, какое счастье, я сломала руку! Нет, Вы не понимаете: какое счастье, что руку, а не ногу!»

О личном. Оксана Герасимовна говорила, что в жизни у нее две привязки: Словарь и сын Ваня. В семье ОГ было трое детей, помимо нее еще два брата, старший и младший. Два мужа. Первый, к которому она до конца дней относилась с необыкновенным почтением, замечательный ученый и педагог Василий Константинович Чичагов, к ее постоянной грусти, рано ушедший из жизни. Второго мужа она очень уважала долгие годы: он пришел с войны с тяжелым ранением, был судьей, честным и бескомпромиссным. Но потом пути их разошлись, они развелись, когда Оксане Герасимовне было уже за 70. Семья Оксаны Герасимовны это сын Ваня и невестка Хильда.

$$
* * *
$$

Когда в социальных сетях ${ }^{1}$ появился некролог по поводу смерти Оксаны Герасимовны, так или иначе на него откликнулось более ста человек; как правило, это были ученики и коллеги Оксаны Герасимовны, преподаватели и научные работники из России и зарубежья.

$\overline{{ }^{1} \text { www.facebook.com/permalink.php?story_fbid }=2101440533247318 \& d=100001441746688}$ 
Вот реплики некоторых ее учеников: Боже мой! Оксана Герасимовна! Царствие ей небесное! Уходят мои учителя... Тоже училась у нее (диалектология). Сколько же народу она выучила!.. Горжусь, что я тоже когда-то у нее училась... Светлая память! Вспоминаю, как Оксана Герасимовна вела в нашей группе историческую грамматику, а потом мы ездили на практику в Лешуконский район под ее руководством... Фантастическая женщина. Несгибаемая. Когда-то мне удалось успешно сдать ей старослав с первого раза. Горжусь до сих пор... Она вела у нас семинары по старославу, я сдала на 4 и была счастлива. Она была требовательной и очень знающей. И человечной... Оксана Герасимовна была для многих катализатором, мою жизнь она точно изменила. Благодаря ей я побывала на Русском Севере. Влюбилась в него, и эта любовь осталась со мной на всю жизнь. Она была строгим и требовательным преподавателем и вместе с тем неподражаемо очаровательной, теплой, понимающей и человечной за пределами университетской аудитории. Все эти дни вспоминаются милые и дорогие сердцу подробности...

Реплики коллег-диалектологов: Больно. Ушел из жизни большой ученый и хороший человек... Ушел большой ученый и замечательная женщина... Замечательный ученый и милейший человек... Незаменимые люди есть, и среди них Оксана Герасимовна!.. Оксана Герасимовна - это истинный, образцовый диалектолог... Основы современной российской диалектологии и диалектной лексикографии...

Пришли соболезнования от коллег из университетов и академических институтов.

Оксана Герасимовна воспитала много учеников. Создала коллектив «Архангельского областного словаря». Очень надеялась, что Словарь будет все-таки закончен. Мы тоже на это надеемся, и сделаем для этого все, что от нас зависит. И тогда память об Оксане Герасимовне Гецовой действительно станет вечной.

Сведения об авторе:

Ирина Борисовна Качинская, канд. филол. наук мл. науч. сотрудник филологический факультет МГУ имени М.В. Ломоносова
Irina B. Kachinskaya,

$\mathrm{PhD}$

Research Associate

Philological Faculty

Lomonosov Moscow State University

kacza@yandex.ru 